\title{
Active Learning in Economic Subject: A Case Study at Secondary School
}

\author{
Ramlee Ismail ${ }^{*}$, Marinah Awang and Seow Yea Pyng \\ Universiti Pendidikan Sultan Idris, Perak, Malaysia \\ https:// orcid.org/0000-0002-0511-0343 \\ https://orcid.org/0000-0001-7734-6366 \\ https://orcid.org/0000-0002-7720-4875 \\ Muhammad Ridhuan Bos Abdullah \\ Universiti Utara Malaysia, Malaysia \\ https://orcid.org/0000-0003-2018-8605
}

\begin{abstract}
This study aims to investigate the impact of active learning in the economics subject in Perak secondary school on students' achievement, motivation, interest, and social interaction. This study applies a quasi-experimental research design, which involves the control and the treatment groups with thirty and thirty-four participants, respectively. The active learning materials for the treatment group were based on active learning methods provided by the Ministry of Education with support from structured lesson plans namely: simulations, discussions, brainstorming, case studies, and visits in the school's compound. A questionnaire is also used to measure students' motivation, interest and social interaction before and after the intervention. The results showed that students who had experienced active learning activities score higher than their counterparts significantly for topic 1 and 2. Besides, findings show that they were motivated and interested in learning economics through active learning compared to the traditional approach. However, the researchers find that the social interaction element is not as significant as the others. It has been concluded that the active learning method attracts student's interest and motivation in the economic subject and subsequently improves their achievement. Students also will get benefit from the varieties of teaching method with a focus of learning outcomes to enrich student-learning activities.
\end{abstract}

Keywords: active learning; economics education; experimental study; teaching economic

\footnotetext{
"Corresponding author: Ramlee Ismail; Email: ramlee@fpe.upsi.edu.my
} 


\section{Introduction}

The subject of Economics has long been taught in Malaysian secondary schools under the Secondary Schools Integrated Curriculum since 1991. This subject aims to provide the basic knowledge to students to enable them to understand its principles in the modern world. The fundamentals of economics for secondary schools will assist students in making rational economic decisions in their daily lives. It helps also to train them to be more critical and creative in their thinking (Ministry of Education, 2015). Add to this, Generic skills such as interpersonal skills, managing and problem solving would be emphasised through this subject (Ministry of Education, Malaysia, 2005). Typically, the economic subject is more likely to use traditional methods such as lectures (chalk and talk), note-taking and it is teacher-centered. Benzing and Christ (1997) and Allgood, Walstad and Siegfried (2013) emphasised that economics courses feature more chalk and talks than other courses. However, the survey done by Watt and Beckers (2008) had pointed out that some of the changes in the teaching method have slowed down, especially in the use of technologies among young economist. In this vein, the notion of active learning pedagogies, including peer learning, flipped classroom, problem-based learning, cooperative learning, and blended learning, has shaped the teaching learning process. Accordingly, many studies revealed that the active learning method is successfully increasing the students' understanding of economics contents (Tatsumi, 2012; Johnson \& Meder, 2019). However, few studies investigate the effect of active learning in secondary or high school.

In the secondary school contexts, learning economics is associated with the fact of memorising activities to prepare for the national examination, compared to student-centered learning process. Consequently, students are less likely to be motivated and are reluctant to its learning. In comparison with another subject such as the Principle of Accounts or Business, the academic achievement in Economics subject is still behind and unsatisfactory. For example, the average numbers of students who passed this subject in the national examination (Malaysian Education Certificate) was 63\%, from 2000 to 2010. In contrast, those who passed the Principle of Accounts and Business have scored 69.9\% and $76.2 \%$ in the same period (Ministry of Education, Malaysia, 2010). Nevertheless, for the last five years, the results have increased by 5\% to give $75.7 \%$ in 2014 and $80.20 \%$ in 2015.

A lower achievement in the economic subject is to certain extent related to students' poor academic background in calculation, the negative attitudes towards the subject, unattractive teaching methods, and the teaching load (Becker \& Watts, 1996, 2001a, 2001b; Watts \& Becker, 2008; Backhouse, 2012). Many educationists believe that students' attitude and motivation towards this subject should cooperate with an attractive teaching method. However, the likelihood of economic teachers using other methods of teaching is lower than teachers of other subjects (Becker, 1998; Watts \& Schaur, 2011). As a reaction, the Ministry of Education in Malaysia (MoE) promotes and encourages active learning because it betters students' performance. Additionally, the teaching learning process that involves active learning in a classroom is more enjoyable 
and exciting (Becker, 1997; Zheng, 2017; Schlehuber, 2017). Therefore, the MoE has introduced a module of Active Learning Practices in Economics since 2005 to help teachers involve in active learning in the classroom (Ministry of Education, Malaysia, 2005). This module covers all topics in the syllabus and teaching materials to support all activities. Yet, it has been observed that there have been no recent developments in active-learning module in the secondary school economic subject. Therefore, the present paper aims to determine whether active learning in the Economics Module could improve secondary school students' interest, motivation, social interaction, and their achievement.

\section{Literature Review}

Simply put, active learning is a method of teaching and learning that involves direct participation of students in the learning process (Ministry of Education, Malaysia, 2005). Students not only learn to do something, but they also think about the actions and decisions taken in those activities (Bonwell \& Eison, 1991; Roach, 2014). According to Silberman (1996) and McLaughin et al. (2013), learning is not about a plain absorption of information into the students' minds, but it also needs the involvement of their minds and actions. The outcomes of active learning will be permanent because they are engaged in tasks that involve higher cognitive thinking skills such as analysis, synthesis, and evaluation (Bonwell \& Eison, 1991; McLaughin, 2013). Thus, students can solve problems that require higher cognitive levels as well as strengthening the skills to think critically and creatively. The benefits of active learning documented with the economics education literature have always been highlighted as one of the teaching method principals (Carlson \& Skaggs, 2000; Ginsburg, 2009; Jensen \& Owen, 2003; Maier \& Keenan, 1994; Manning \& Riordan, 2000; Watts \& Schaur, 2011, Moon, Wold \& Francom, 2017; Zheng, 2017; Bryan \& Jett, 2018). Therefore, active learning in economics education is mandatory (Becker, 1997; Becker \& Watts, 2001a; Hansen, 2001; Salemi, 2002) to be used in the classroom. This method of teaching requires the active involvement of students to achieve sustainable learning outcomes in the economics subject (Cross, 1987; MOE, 2005; Siegfried et al.; 1991; Whiting, 2006). Some empirical studies on active learning find that students who are involved in teaching and learning using this approach performed better than in the traditional approach (Gratton-Lavoie \& Stanley, 2009). Moreover, students' interaction and collaboration in small groups do not only increase, but also will contribute to greater subject materials (Yamarik, 2007; Bryan \& Jett, 2018).

With regard to the above said, the traditional learning process carried out by teachers in the classroom does not highlight the concept of independent learning. Rather, in the teacher-centered learning process, students are given less opportunity to apply or develop their cognitive and affective skills. They only receive the information from their teachers passively and are required to act on what is instructed by the teachers (Prince, 2004). This philosophy is oldfashioned and does not align with the actual role students need to play to survive in the teaching learning process. In this respect, active learning activities such as group discussions, problem-solving, simulations, games and case studies provide students with the opportunity to express and support their ideas as well 
as to consider the thoughts and the opinions of others (Meyers \& Jones, 1993; McCarty, Ford \& Ludes, 2018). With this in mind, students can exchange their ideas and interact freely with their classmates. Additionally, active learning activities can attract students' interest and create a fun, lively and cheerful classroom atmosphere (Salemi, 2002).

In fact, active learning is not only useful in enhancing students' understanding, but it also increases students' achievement (Carlson \& Velenchik, 2006; Bartlett, 2006; Buckles \& Hoyt, 2006; Yamarik, 2007; Filio et al., 2013; Calimaries \& Sauer, 2015; Cavigllia-Harris, 2016; Rita et al., 2016). Carlson and Velenchik (2006) demonstrate that the technique of discussions in the economics class could develop students' analytical thinking skills. Students can apply the economic theory using the information and data provided by their instructor. Meanwhile, Bartlett (2006) finds that the cooperative learning technique in economics education is effective in improving students' academic performances in examinations. Active learning activities provide opportunities for students to acquire higher thinking skills when interpreting economic concepts. In this sense, Rupp (2014) comes across the fact that elementary school students have significant improvements in their understanding of fundamental economic concepts. This situation sharply contrasts with the traditional learning situation where students are merely asked to understand the precise concept from the teacher's explanation (Salemi, 2002).

In the same line of thought, many scholars also realized that active learning can improve students' interest towards the economics subject (Brokaw \& Merz, 2004; Dixit, 2006; Rotgans \& Schmidt, 2011; Strow \& Strow, 2006). Brokaw \& Merz (2004) show that active learning could trigger students' interest in the critical concepts of the economy. Games technique, for example, can improve student's understanding of economic theories that are too abstract for them to comprehend (Dixit, 2006). Furthermore, role-play can also enhance student's interest in the subject, as well as prevents boredom and sleepiness in the classroom. In parallel, teachers should provide guidance, coaching, and motivation that are necessary for students who have difficulties with active learning activities in class (Buckles \& Hoyt, 2006). Also, rewards that are given by teachers to those who did well in a particular activity either in verbal forms, such as praises and encouragement or in material forms such as chocolates or small gifts, will make students more motivated to actively participate in group activities (Slavin, 1990). The latter do not only foster intrapersonal and interpersonal skills among the students, but also inculcate ethical values such as respecting the opinion of others, collaborating and, to be fair and equitable in emphasizing logical facts. In doing so, learner's autonomy and collaboration will increase (Becker, 1997; Bonwell \& Eison, 1991; Johnson, Johnson \& Smith, 1998; Salemi, 2010; Toh Wah Seng; 2008; Bailey et al., 2013; Bergmann et al., 2013), and their interaction improves academic achievement and interest (Brooks \& Kandler, 2002). Which in return give more opportunities and flexibilities to identify their learning style, interests, and abilities (Fuller et al., 2015 \& Mazur et al., 2015). 
Though the significant endeavour done by the MoE and the outstanding materials for effective outcomes, some economics teachers have almost forgotten the existence of this module as most of them prefer the traditional method of instruction which is 'chalk and talk,'. In this context, Hansen at al. (2002) contended that economics teachers or instructors have been slow to adopt the new teaching methods. The common reasons for using the traditional approach in the economics subject includes the large class size, lack of materials, and the many topics covered in the syllabus. Goffe and Kauper (2014) suggest that the predominant reason why teachers prefer to use the lecturing method in the economics subject is the ability to control the delivery and coverage of content. In the Malaysian context, teachers complained that they are reluctant with nonrelated teaching activities at school such as too much clerical work, data entering, and preparing the students for various competitions at school, district, state and national levels. A survey has been carried out on the teacher's workload in Malaysia and findings show that the average number of hours is 57 hours per week, but some of them have workload up to 76 hours per week. Unfortunately, the proportions of time spent in preparing teaching activities were low (MoE, 2013). Indeed, when the educational system is streaming into so-called science and art, economics students then fall into the 'second category' wherein the likelihood of passivity and anonymity exists and therefore becomes a barrier of active teaching and learning ( Hoyt at al., 2010; Roach, 2014). The quality of learning also depends on learners' abilities to steer and control their learning processes (Niemi, 2002) and past performance (Denny, 2014). The outcome of students' achievement is measured by "how many got A's or how many per cent passed the economics subject" which is in fact not an encouraging statement teachers appreciate to spend more time on effective classroom management, solid planning teaching materials, and activities. However, these are not the ultimate reasons why the active teaching and learning module by MoE should be left behind. Hence, the researcher's rationale is to study the effectiveness of the current teaching method, using the materials provided by the MoE, to improve students' interest, motivation, social interaction and achievement in the Economics subject at secondary schools.

\section{Methodology}

The conceptual framework for this study adopted the three-phase learning model introduced by Biggs (1978). The first phase of the survey is a pre-study, which refers to the pre-review factors of active learning namely: student's achievement, interest, motivation and social interaction of students in an Economic subject. The second phase involves the process of teaching and learning (T\&L), which is active learning that was carried out in the Form Four economics classes. In hope to meet the intended results, discussions, simulations, brainstorming, case studies and visits within the school's compound are the five active learning activities the researchers have used in this research paper. These learning activities are indeed extracted from the "Best Active Learning Practices in Fundamental Economics" as provided by MoE. The materials and tools for these learning activities will further enhance the effectiveness of student's learning in the final phase. Figure 1 shows the three phases. 


\begin{tabular}{lll}
\hline Pre-review of the effectiveness & $\begin{array}{l}\text { Teaching \& learning process - } \\
\text { Active learning }\end{array}$ & Output \\
\hline - Academic achievement & $\begin{array}{l}\bullet \text { Discussions } \\
\text { - Interest }\end{array}$ & $\begin{array}{l}\text { - Academic } \\
\text { achievement }\end{array}$ \\
- Motivation & $\bullet$ Brainstorming \\
- Social interaction & $\bullet$ Case studies & $\begin{array}{l}\text { - Interest } \\
\text { - Motivation } \\
\end{array}$ \\
& $\bullet$ Visit school compound & $\begin{array}{l}\text { - Social } \\
\text { interaction }\end{array}$ \\
\hline
\end{tabular}

Figure 1. Active Learning Process in Teaching and Learning of Fundamental Economics

This research is a quasi-experimental design which is used to test whether there are any significant effects of active learning and the traditional methods on the academic achievement of students in the Form Four FE subject. Also, the researchers used a questionnaire to obtain students' feedback on the effectiveness of active learning methods in their economics class. The questionnaire is administered to sixty-three participants and it consists of two sections. The first section covers information on the personal background of the respondents such as gender, parent's educational level, and others. Whereas, section two is meant to collect data on the respondents' interest, motivation, and social interaction using the five Likert scale. The questionnaire is adapted from Motivated Strategies for Learning Questionnaire - MSLQ research tool, which was developed by Pintrich and DeGroot (1990). This MSLQ survey tool has been widely used to measure the level of motivation in students' learning. Meanwhile, social interaction instruments have been modified from the Inventory of Parent and Peer Attachment (IPPA) survey by Armsden and Greenberg (1987).

Preliminary test (pretest) and performance tests (posttest) are used to measure students' basic knowledge, and evaluate their academic achievement, respectively. These tests are developed by the researchers in which they are based on the Malaysian Certificate Education Examination and certified by an expert from the same state. Indeed, the preliminary test is used as a covariate to streamline the fundamental difference between treatment and control groups. The present study takes place in Perak secondary school where the researchers explicitly introduced the studied criteria and the materials to be used in both groups (treatment group, $\mathrm{N}=34$ and Control group, $\mathrm{N}=30$ ). The investigators have used random sampling method to group the participants based on their registration number, but those with odd registration number are reallocated to the treatment group, including those with registration number who are in the control group. The control class is used to eliminate the variation effect of the student's knowledge and economics background. The same teacher teaches both classes on the same topics but with different methods. The experiment lasts for four weeks, which covers Unit 5 with the Topic: Market. The teaching load is "2 +1 " per week, which is 80 and 40 minutes for each session. The materials and lesson plans used were Active Learning Module from page 148 to 167; covering 
11 teaching materials with four main activities namely: brainstorming, role play, simulation and group work. The control group uses a traditional method.

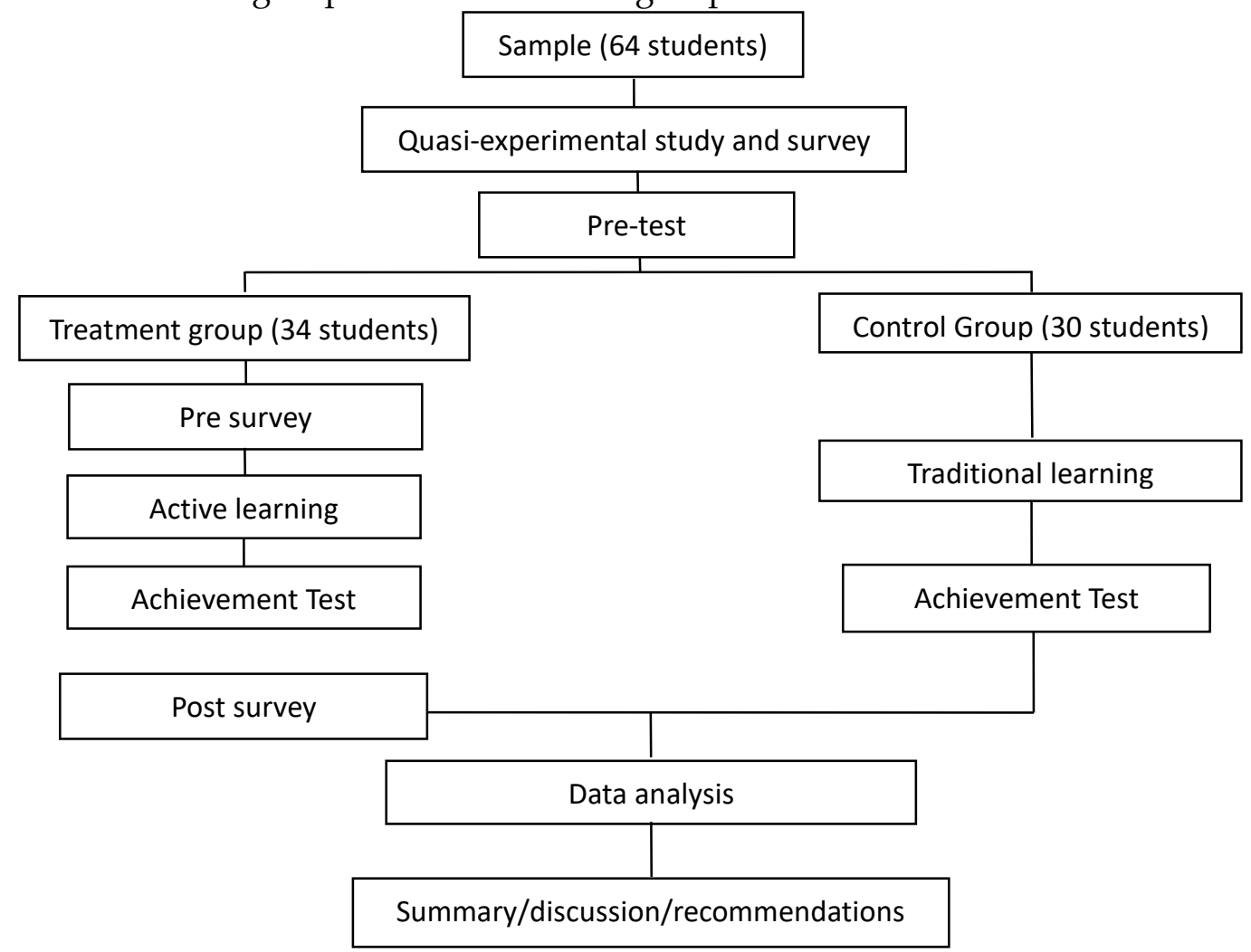

Source: Modified from Shadish, Cook, and Campbell (2002)

Figure 2: The Intervention vs the Traditional Method

The researchers have also provided plans to be used in daily lessons according to topics, reference materials, papers, and other group activities to help instruct others entirely. Also, guidance and answers for teachers are also provided to ensure that active learning activities are carried out smoothly in the economics class. A summary of the activities for both methods is shown in Table 1.

Table 1: Comparison of Active and Traditional Learning Methods

\begin{tabular}{|c|c|}
\hline Active Learning & Traditional Learning \\
\hline $\begin{array}{l}\text { Students were introduced to study } \\
\text { topics through an impressive set of } \\
\text { Induction. }\end{array}$ & $\begin{array}{l}\text { The teacher introduced the lesson topic } \\
\text { through a brief question and answer }\end{array}$ \\
\hline $\begin{array}{c}\text { Teaching activities using active learning } \\
\text { materials. }\end{array}$ & $\begin{array}{l}\text { The teacher presented the lesson } \\
\text { content by using the lecture method. }\end{array}$ \\
\hline $\begin{array}{l}\text { Students complete the individual and } \\
\text { groups' learning materials }\end{array}$ & Students listen to while taking notes \\
\hline $\begin{array}{l}\text { The conclusion made by students or } \\
\text { teachers at the closing session }\end{array}$ & $\begin{array}{l}\text { The teacher made a summary at the } \\
\text { closing session }\end{array}$ \\
\hline $\begin{array}{c}\text { Students do the activities in the form of } \\
\text { active learning }\end{array}$ & $\begin{array}{c}\text { The teacher gave a few questions for } \\
\text { homework }\end{array}$ \\
\hline
\end{tabular}




\section{Results}

Descriptive statistics were used to describe the demographical factors of our sample. Table 2 depicts some students' background for both groups. The male sample was slightly larger than the female sample in the treatment group compared to the control group. Table 2 summarises the collected data on the respondents' background information.

Table 2: Background Profile of the Study's Respondents ( $n=64)$

\begin{tabular}{|c|c|c|}
\hline & Treatment Group & Control Group \\
\cline { 2 - 3 } Item & $\mathbf{n}(\mathbf{\%})$ & $\mathbf{n}(\mathbf{\%})$ \\
\hline Gender & & \\
Male & $19(55.9)$ & $13(43.3)$ \\
Female & $15(44.1)$ & $17(56.7)$ \\
\hline Parents' education & & \\
Primary school & $7(20.6)$ & $7(23.3)$ \\
Secondary school & $25(73.5)$ & $23(76.7)$ \\
Tertiary education & $2(5.9)$ & - \\
\hline Parents' / Guardian's Employment & $11(32.4)$ & $8(26.7)$ \\
Government Employees & $6(17.6)$ & $7(23.3)$ \\
Private Sector Employees & $13(38.2)$ & $11(36.7)$ \\
Self-employed & $4(11.8)$ & $4(13.3)$ \\
Retirees & & \\
Total Monthly Household Income & $21(61.8)$ & $20(66.7)$ \\
Less than RM 1000 & $8(23.5)$ & $7(23.3)$ \\
RM 1000 - RM 1500 & $4(11.8)$ & - \\
RM 1501 - RM 2000 & $1(2.9)$ & $3(10.0)$ \\
More than RM 2000 & &
\end{tabular}

The differential in the mean score of active learning activities in the classroom is tested by the Paired Sample T-Test and analysis of covariance (ANCOVA) for the achievement test. The difference between the mean scores for the treatment group before and after involvement in the active learning process is compared and determined whether there were any significant differences between the two data sets. The Paired Sample t-test is used to test whether there is any significant increase in interest, motivation and social interaction in the treatment group after they have experienced the activities that were carried out using the active learning method. While, the ANCOVA technique is used to eliminate the existence of economics knowledge of the two groups that were involved in the current attempt (Shadish, Cook \& Campbell, 2002). A covariate uses the latest monthly assessment for both groups as the pre-test. Column five in Table 3 depicts students' achievement in the first and second topics.

Table 3: Analysis of Covariance

\begin{tabular}{|c|c|c|c|c|c|c|}
\hline Experiment & Topic & Group & $\mathbf{N}$ & $\begin{array}{l}\text { Mean Test } \\
\text { Performance }\end{array}$ & F & $\mathbf{p}$ \\
\hline $\begin{array}{c}\text { Active } \\
\text { learning }\end{array}$ & 1 & $\begin{array}{c}\text { Control } \\
\text { Treatment }\end{array}$ & $\begin{array}{l}30 \\
33\end{array}$ & $\begin{array}{l}53.00 \\
61.52\end{array}$ & 73.181 & 0.000 \\
\hline & 2 & $\begin{array}{c}\text { Control } \\
\text { Treatment }\end{array}$ & $\begin{array}{l}30 \\
33\end{array}$ & $\begin{array}{l}56.00 \\
67.42 \\
\end{array}$ & 92.659 & 0.000 \\
\hline
\end{tabular}


As displayed, the mean score for the treatment group was higher than the control group in both topics. The findings show that the academic achievement of students who used active learning activities was significantly higher than their counterpart with the $\mathrm{F}=92.66$.

Table 4 reflects the results of students' experience in active learning. The mean difference between pre and post-survey for "Interest, Motivation, and Social Interaction" are shown in column three. The positive value indicates that the average score for post-test is higher than the pre-test.

Table 4: Paired Sample t-test

\begin{tabular}{|c|c|c|c|c|}
\hline Variables & $\begin{array}{c}\text { Mean difference after and } \\
\text { before treatment }\end{array}$ & $\mathbf{d f}$ & $\mathbf{t}$ value & Sig. (two tails) \\
\hline Interest & 1.817 & 33 & 14.240 & 0.000 \\
\hline Motivation & 1.425 & 33 & 10.572 & 0.000 \\
\hline Social Interaction & 0.225 & 33 & 1.688 & 0.101 \\
\hline
\end{tabular}

The significant or the non-significant of the mean difference in these activities depends on the $t$ value. Therefore, the $t$ value for "Interest and Motivation" is, $t$ $(33, \mathrm{p}=0.000)=14.24$ and $\mathrm{t}(33, \mathrm{p}=0.00)=10.57$ respectively, which was smaller than 0.05 which indicates that both variables are significant. That is to say, the active learning activities conducted in the classroom enabled students to show more interest and motivation in learning the economics subject. However, as displayed, there is no significant difference in the mean score of "Social Interaction" before and after learning activities.

\section{Discussion and Conclusions}

This study concludes that the treatment group with the notion of active learning method performs better than those following the traditional learning process in the control group. In this regard, some studies also showed that active learning had improved students' academic achievement, (Budd, 2004; Johnson \& Johnson, 1994; Johnson, Johnson \& Smith, 1998; Meyers \& Jones, 1993; Roche, 2014 and Slavin, 1995). However, Malek, Hall and Hodget (2014) found that there is no statistically significant improvement when the traditional teaching methods were tested with the alternative teaching method. The findings of the current paper dictate that students become more motivated in learning economics using the active teaching and learning method. These findings are also found by other researchers namely, Bartlett (2006), Becker (1997), Bonwell and Eison (1991), Brokaw and Merz (2004), Carlson and Velenchik (2006), Dixit (2006), Hazlett (2006) and Salemi (2002).Students are fond of the active learning activities conducted in class mainly in simulations, group discussions, case studies and visits within the school's compound. They approach these practices as being attractive and fun which help them to understand the concepts of economics better. More than that, active learning methods can also enhance students' motivation in the process of learning economics for Form Four. Although the application of motivational research to the economics subject is scarce, there is some evidence that motivation is an additional factor to successful output in economics among students (Arnold \& Straten, 2012), 
because the teaching aids and materials in active learning are rewarding and fun for students (Salemi, 2002). Nevertheless, results of the current endeavour do not show the mean difference before and after experiment on the aspect of social interaction. That is to say, it appears that there is no conclusive evidence that the active learning method is effective in improving the social interaction of students. Probably, changes in a class setting should be included in preparing class activities. Because, active learning classroom (ACL) is a common setting and arrangements for enhance effective learning process (Baepler \& Walker, 2014; Metzger, 2015), the latter will contribute to make a significant impact on social interaction with new team members and foster a closer relationship with new friends. As far as economics teachers are concerned, they should not solely rely on traditional learning methods, as a reason, to complete the syllabus given for a large number of students in a class. The active teaching materials provided by educational department should be frequently used, diversified and blended with latest teaching and learning devices to motivate students. Indeed, further empirical studies should explore promising alternatives to enable learners understand the significant role social interaction plays and what pedagogies to develop for successful integration.

\section{References}

Allgood, S., Walstad, W. B., \& Siegfried, J. J. (2015). Research on teaching economics to undergraduates. Journal of Economic Literature, 53(2), 285-325.

Armsden, G. C., \& Greenberg, M. T. (1987). The inventory of parent and peer attachment: relationships to well-being in adolescence. Journal of Youth and Adolescence, 16(5), 427-454.

Arnold, I. J. M., \& Straten, J. T. (2012). Motivation and math skills as determinants of first-year performance in economics. The Journal of Economic Education, 43(1), 33 47.

Baepler, P., \& Walker, J. D. (2014). Active learning classrooms and educational alliances: Changing relationships to improve learning. New Directions for Teaching and Learning, 2014(137), 27-40. doi:10.1002/tl.20083

Bartlett, R. L. (2006). The evolution of cooperative learning and economics instruction. In W. E. Becker, M. Watts \& S. R. Becker (Eds.), Teaching Economics: more alternatives to chalk and talk (pp. 39-58). Cheltenham: Edward Elgar Publishing Limited.

Becker, W. E. (1997). Teaching economics to undergraduates. Journal of Economic Literature, 35(9), 1347-1373.

Becker, W. E. (1998). Engaging student in quantitative analysis with the academic and popular press. In W. E. Becker \& M. Watts (Eds.), Teaching Economics: more alternatives to chalk and talk (pp. 241-267). Cheltenham, UK: Edward Elgar Publishing Limited.

Becker, W. E., \& Watts, M. (1996). Chalk and talk: A national survey on teaching undergraduate economics. American Economic Review, 86(2), 448-453.

Becker, W. E., and M. Watts. (2001a). Teaching economics at the start of the 21st century: Still chalk-and-talk. American Economic Review, 91(2), 446-51.

Becker, W. E., \& M. Watts. (2001b). Teaching methods in U.S. undergraduate economics courses. Journal of Economic Education, 32, 269-279.

Benzing, C., \& Christ, P. (1997). A survey of teaching methods among economics faculty. The Journal of Economic Education, 28(2), 182-188.

Biggs, J. B. (1978). Individual and group differences in study processes. British Journal of Educational Psychology, 48, 266-279. 
Bonwell, C. C., \& Eison, J. A. (1991). Active Learning: Creating Excitement in the Classroom. ASHE-ERIC Higher Education Report No. 1. Washington, DC: The George Washington University, School of Education and Human Development.

Brokaw, A. J., \& Merz, T. E. (2004). Active Learning with Monty Hall in a Game Theory Class. Journal of Economic Education, 35(3), 259-268.

Bryan, N., \& Jett, C. C. (2018). "Playing school": Creating possibilities to inspire future Black male teachers through culturally relevant play. Journal for Multicultural Education, 12(2), 99-110. https:/ / doi.org/10.1108/JME-04-2017-0024

Brooks, T. B., \& Khandker, A. W. (2002). A Collaborative Learning Lab: Does The Form Matter? Contemporary Economic Policy, 20(3), 330-338.

Buckles, S., \& Hoyt, G. M. (2006). Using Active Learning Techniques in Large Lecture Classes. In W.E. Becker, M. Watts \& S.R. Becker (Eds.), Teaching economics: More alternatives to chalk and talk (pp. 75-88). Cheltenham, UK: Edward Elgar Publishing.

Budd, J. W. (2004). Mind maps as classroom exercises. Journal of Economics Education, 35(1), 35-46.

Carlson, J. L., \& Skaggs, N.T. (2000). Learning by trial and error: A case for moot courts. Journal of Economic Education, 31(2), 145-155.

Carlson, J. A., \& Velenchik, A. (2006). Using the Case Method in the Economics Classroom. In W.E. Becker, M. Watts \& S.R. Becker (Eds.), Teaching economics: More alternatives to chalk and talk (pp. 59-74). Cheltenham, UK: Edward Elgar Publishing.

Cross, P. K. (1987). Teaching for learning. AAHE Bulletin, 39(8), 2-7.

Denny, E. (2014). Factors influencing the performance of non-economics majors in an introductory economics course. International Review of Economics Education, 17, 116.

Dixit, A. (2006). Restoring Fun to Game Theory. In W.E. Becker, M. Watts \&S.R. Becker (Eds.), Teaching Economics: more alternatives to chalk and talk (pp. 1-20). Cheltenham, UK: Edward Elgar Publishing.

Goffe, W. L., \& Kauper, D. (2014). A Survey of Principles Instructors: Why Lecture Prevails. The Journal of Economic Education, 45(4), 360-375. doi:10.1080/00220485.2014.946547

Ginsburg, M. (2009). Active learning pedagogies as a reform initiative: Synthesis of case studies. Washington, DC: Academy for Educational Development.

Hansen, W. L. (2001). Expected Proficiencies for undergraduate economics majors. Journal of Economic Education, 32(3), 231-242.

Hazlett, D. (2006). Using Classroom Experiments to Teach Economics. In W.E. Becker, M. Watts \& S.R. Becker (Eds.), Teaching economics: More alternatives to chalk and talk (pp. 21-38). Cheltenham, UK: Edwar Elgar Publishing.

Hoyt, G., Kassis, M., Vera, D., \& Imazeki, J. (2010). Making cooperative learning effective for economics. In W. B. Walstad \& M. K. Salemi (Eds.), Teaching innovations in economics: Strategies and applications for interactive instruction (pp. 65-94). Cheltenham, UK: Edward Elgar Publishing.

Jensen, E. J., \& Owen, A. L. (2003). Appealing to good students in introductory economics. Journal of Economic Education, 34(4), 299-325.

Johnson, D. W., \& Johnson, R. T. (1994). Learning together and alone: Cooperative, competitive and individualistic learning. Boston: Allyn \&Bacon.

Johnson, D. W., Johnson, R. T., \& Smith, K. A. (1998). Cooperative learning returns to college: What evidence is there that it works?, Change, 30, 26-35.

Johnson, M., \& Meder, M. (2019). A Meta-Analysis of Technology Interventions in Collegiate Economics Classes. Journal of Economic Education, 1-27. doi:10.2139/ssrn.3501227 
Maier, M. H., \& Keenan, D. (1994). Teaching Tool: Cooperative learning in economics. Economic Inquiry, 32(2), 358-361.

Malek, N. P., Hall, J. P., \& Hodges, C. (2014). A review and analysis of the effectiveness of alternative teaching methods on student learning economics. Perspectives on Economic Education Research, 9(1), 75-85.

Manning, L. A., \& Riordan, C. A. (2000). Using groupware software to support collaborative learning in economics. Journal of Economic Education, 31(3), 244-252.

Meyers, C., \& Jones, T.B. (1993). Promoting active learning: Strategies for the college classroom. San Francisco: Jossey-Bass.

Metzger, K. J. (2015). Collaborative teaching practices in undergraduate active learning classrooms: A report of faculty team teaching models and student reflections from two biology courses. Bioscene, 41(1), 3-9.

Moon, A. L., Wold, M. C., \& Francom, G. M. (2017). Enhancing reading comprehension with student-centered iPad applications. G. M. Tech Trends, 61(2), 187-194.

Ministry of Education (MoE). (2005). The best practice of active learning in Fundamental Economics (Amalan Terbaik Pembelajaran Aktif Dalam Ekonomi Asas). Kuala Lumpur: Pusat PerkembanganKurikulum.

Ministry of Education (MoE). (2010). AnalisisKeputusan Peperiksaan SPM 2000-2009. Kuala Lumpur: Lembaga Peperiksaan Malaysia.

Ministry of Education (MoE). (2013). Malaysia Education Blueprint 2013 - 2015. Kuala Lumpur: Ministry of Education (MoE).

Ministry of Education (MoE). (2015). Kurikulum Standard Sekolah Menengah: Ekonomi. Kuala Lumpur: Ministry of Education (MoE).

Niemi, H. (2002). Active learning - a cultural change needed in teacher education and schools. Teaching and Teacher Education, 18(7), 763-780.

Pintrich, R. R., \& DeGroot, E. V. (1990). Motivational and self-regulated learning components of classroom academic performance. Journal of Educational Psychology, 82(1), 33-40.

Prince, M. (2004). Does Active Learning Work? A Review of the Research. Journal of Engineering Education, 93(3), 223-231.

Roach, T. (2014). Student perceptions toward flipped learning: New methods to increase interaction and active learning in economics. International Review of Economics Education, 17, 74-84.

Roche, K. (2014). An active-learning exercise on learning negotiation as a way to mitigate the gender wage gap for introductory microeconomics. International Review of Economics Education, 1, 32-42.

Rotgans, J. I., \& Schmidt, H. G. (2011). The role of teachers in facilitating situational interest in an active-learning classroom. Teaching and Teacher Education, 27(1), 3742.

Rupp, N. G. (2014). Teaching economics with a bag of chocolate: A classroom experiment for elementary school students. International Review of Economics Education, 16, $122-128$

Salemi, M. K. (2002). An Illustrated Case for Active Learning. Southern Economic Journal, 68(3), 721-731.

Salemi, M. K. (2010). Developing teacher expertise for economists through a workshop experience. In M. K. Salemi, \& W. B. Walstad (Eds.), Teaching innovations in economics: Strategies and applications for interactive instruction (pp. 1-24). Cheltenham, UK: Edward Elgar Publishing.

Schlehuber, L. (2017). The future of student life: Learning. On the Horizon, 25(3), 169-172. doi:10.1108/OTH-05-2017-0023.

Shadish, W. R., Cook, T. D., \& Campbell, D. T. (2002). Experimental and QuasiExperimental Designs for Generalized Causal Inference. Boston: Houghton Mifflin. 
Siegfried, J. J., Bartlett, R., Hansen, W. L., Kelley, A. C., McClosky, D. N., \& Tietenberg, T. H. (1991). Thestatus and prospects of the economics major. Journal of Economic Education, 22(3), 195-224.

Silberman, M. L. (1996). Active Learning: 101 strategies to teach any subject. London: Allyn and Bacon.

Slavin, R. E. (1990). Research on cooperative learning: Consensus and controversy. Educational Leadership, 47(4), 52-54.

Slavin, R. E. (1995). Cooperative learning: Theory, research, and practice. Massachusetts: Allyn \& Bacon.

Strow, B. K., \& Strow, C. W. (2006). A Rent-Seeking Experiment for the Classroom. Journal of Economic Education, 37(3), 323-330.

Yamarik, S. (2007). Does Cooperative Learning Improve Student Learning Outcomes? Journal of Economic Education, 38(3), 259 - 277.

Watts, M., \& Schauer, G. (2011). Teaching and assessment methods in undergraduate economics: A fourth national quinquennial survey. Journal of Economic Education, 42,294-309.

Whiting, C. (2006). Data-based Active Learning in the Principles of Macroeconomics course: A Mock FOMC Meeting. Journal Economics of Education, 37(2), 171-177.

Zheng, X. (2017). Research on the student-centered learning in mass media reading course. Theory and Practice in Language Studies, 7(3), 227-233. doi:10.17507/tpls.0703.09 